\title{
Adenomyotic cyst of the uterus associated with pelvic pain: A case report
}

\author{
Pelvik ağrı ile ilişkili uterusun adenomyotik kisti: Olgu sunumu \\ Berna Dilbaz, Özlem Şengül, Tuba Zengin, Hatice Dilek Bülbül, Leyla Mollamahmutoğlu
}

\begin{abstract}
Adenomyotic cysts of the uterus are extremely rare and this case report is to document an adenomyotic cyst of the uterus associated with pelvic pain. A 27-year old nulliparous patient admitted to the hospital with the complaint of dysmenorrhea, dyspareunia and pain in the right pelvic region for the last 3 months. Transvaginal ultrasonographic examination revealed a $50 \times 36 \mathrm{~mm}$ intramural cystic lesion on the right region of the corpus uteri. Hysteroscopic examination showed that it did not deteriorate the endometrial cavity. During laparatomy dissection of the uterine wall revealed $5 \mathrm{~cm}$ cystic lesion that was excised circumferentially protecting the surrounding myometrial tissue. The definitive pathology report came out as adenomyotic tissue. Imaging techniques are critical in differential diagnosis of adenomyotic cysts and to choose the appropriate intervention. Medical therapy or surgical intervention like excision of the cyst or hysterectomy may be the choices of treatment. J Clin Exp Invest 2014; 5 (1): 100-102
\end{abstract}

Key words: Adenomyotic cyst, pelvic pain, laparatomy

\section{INTRODUCTION}

Adenomyosis is the presence of endometrial glands and stroma placed in the uterine myometrium. Diffuse adenomyosis is the most common form of adenomyosis; but focal adenomyosis in the form of adenomyoma, cystic adenomyosis, or adenomyotic cyst may also be seen [1]. Adenomyotic cysts of the uterus are extremely rare. The potential mechanisms of pathophysiology of adenomyosis can be explained by endomyometrial invagination or estrogen stimulation of Mullerian remnants or iatrogenic implantation during uterine surgery [1]. Adenomyosis is usualy a diffuse disease but rarely may be a focal lesion [1]. We aimed to present this case report which was associated with pelvic pain.

\section{ÖZET}

Uterusun adenomyotik kistleri çok nadirdir ve bu vaka sunumunda pelvik ağrı ile ilişkili uterusun adenomyotik kisti sunulmuştur. 27 yaşındaki nulligravid hasta dismenore, disparenü ve son 3 aydır devam eden sağ pelvik ağrı şikayeti ile hastaneye başvurmuştur. Transvajinal ultrasonografide uterus korpusunun sağında $50 \times 36 \mathrm{~mm}$ intramural kistik lezyon saptandı. Histeroskopik incelemede lezyonun endometrial kaviteyi etkilemediği izlendi. Laparatomi sırasında çevre myometrial doku korunarak 5 $\mathrm{cm}$ boyutundaki kist çepeçevre diseke edilerek çıkarıldı. Patoloji sonucu adenomyotik doku olarak geldi. Görüntüleme yöntemleri adenomyotik kistlerin ayırıcı tanısında ve uygun tedavinin seçiminde önemlidir. Medikal tedavi veya kistin eksizyonu ya da histerektomi gibi cerrahi yaklaşımlar tedavi seçenekleri olabilir.

Anahtar kelimeler: Adenomyotik kist, pelvik ağrı, laparatomi

\section{CASE}

A 27 year old nulligravid patient was admitted to our hospital with the complaint of dysmenorrhea, dyspareunia and pain in the right pelvic region for the last 3 months. Her menstrual cycle was regular and she had no menorrhagia. She had no history of any other disease or operation. The vital signs of the patient were normal. On gynecological examination a tender uterus slightly larger than normal was palpated. Complete blood count, basic biochemical tests were normal, serum $\beta-\mathrm{HCG}$ level was within no pregnant values. Urinalysis, cervical and urinary cultures were negative. Transvaginal ultrasonographic examination revealed a $50 \times 36 \mathrm{~mm}$ intramural cystic lesion with homogeneous internal 
echogenities on the right region of the corpus uteri (Figure 1). Magnetic resonance imaging of the patient revealed $52 \times 46 \mathrm{~mm}$ lesion with internal fluid located in the myometrium on the right side of the corpus uteri. Adenomyotic cyst, cystic degeneration of intrauterine leiomyoma were firstly thought in the differential diagnosis and hysteroscopy and laparatomy were planned. Informed consent covering permission for documentation of the case was taken from the patient before the operation.

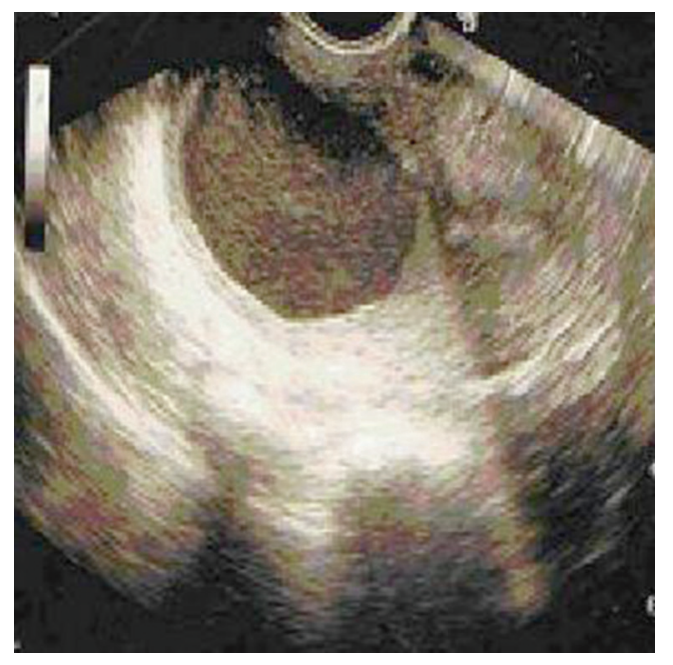

Figure 1. The ultrasonographic image of the adenomyotic cyst

The patient was prepared for the operation and draped in litotomy position. At first hysteroscopy done to evaluate the relationship between the cyst and the endometrial cavity and it has been documented that the cytic lesion did not deteriorate the endometrial cavity. Laparatomic exploration showed that the uterus was enlarged and there was a mass on the right side of the corpus uteri. Both ovaries and fallopian tubes were normal in appearance, no endometriotic lesion was detected. Dissection of the uterine wall above the mass revealed a $5 \mathrm{~cm}$ cystic lesion that was excised circumferentially protecting the surrounding myometrial tissue. The wellcircumscribed cyst ruptured during disection and dark brown fluid was expelled. Excision of the cystic wall was done without entering the endometrial cavity (Figure 2). Intraoperatively the frozen section of the cyst wall was reported as benign. The definitive pathology report came out as adenomyotic tissue. The patient was discharged from the hospital on the second day of the operation and the follow-up and recovery period was uneventful. Her symptoms of pain were dissolved one month after the operation.

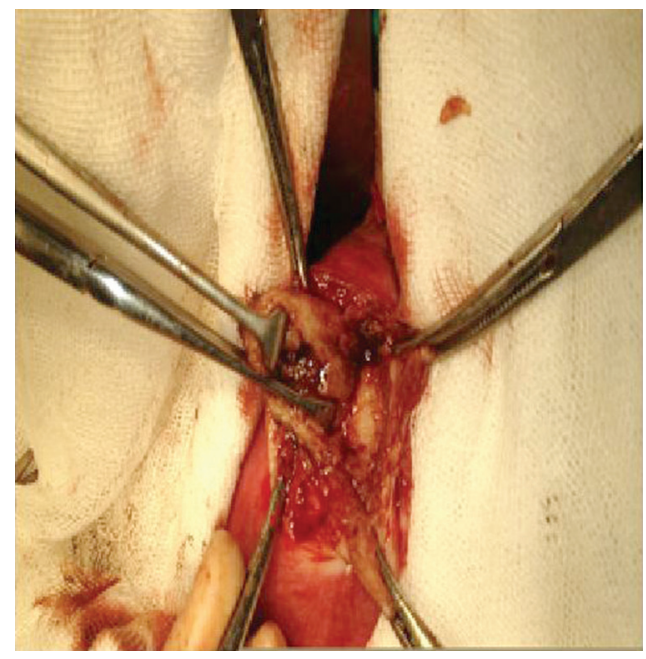

Figure 2. The adenomyotic cyst of the uterus

\section{DISCUSSION}

Cystic lesions of the uterus are rare lesions and are considered to be benign [2]. Adenomyotic cysts are usually observed in parous women, and usually seen in association with diffuse adenomyosis uteri [3]. But isolated adenomyotic cysts may also be detected $[4,5]$. Adenomyotic cysts are usually seen in older ages but they may be even detected in adolescents [5]. Small adenomyotic cysts that do not usually exceed $5 \mathrm{~mm}$ in diameter are found in $24 \%$ of hysterectomy specimens [6] but larger adenomyotic cysts are extremely rare. Repeated surgical intervention may be a risk factor for adenomyotic cysts [7]. Pelvic pain, dysmenorrhea, menorrhagia and larger sized uterus are the most common clinical features of adenomyosis. But even urinary retension may be the symptom of an adenomyomatous polyp [8]. Pain or severe dysmenorrhea may also be the main symptom in adenomyotic cysts $[2,4,5]$. This patient had also pelvic pain as the main symptom accompanied by dysmenorrhea and postcoital pain. The pain of the adenomyotic cyst may be attributed to the progressive increase in size of the mass, stretching of the endometrial cavity and intracystic bleeding [5].

Magnetic resonance imaging is important for the accurate diagnosis of cystic adenomyosis especially when findings from other imaging modalities are nonspecific [9]. Magnetic resonance imaging can easily differentiate multiple cysts within the uterine myometrium, but hysterosalpingography may also be useful for the differential diagnosis when magnetic resonance imaging cannot differentiate isolated adenomyotic cyst from cavitated noncommunicating rudimentary uterine horn [4]. 
Imaging techniques are critical in differential diagnosis of adenomyotic cysts and help us to choose the appropriate intervention by also taking into account the size and the localization of the cyst and age of the patient. In young patients hormonal ablative therapy is the first choice and can be accomplished by combined oral contraceptives. In the presence of severe symptoms that do not diminish with medical therapy, a surgical intervention can be planned that aims total excision of the adenomytic cyst. An abdominal intervention has the advantages of precise restoration of the uterine cavity over laparoscopic aproach but various other techniques such as hysteroscopy can be recommended for excision depending on the localization of the cyst [10]. In older patients with no desire to preserve their fertility and especially in cases when adenomyotic cysts are accompanied by diffuse adenomyosis, hysterectomy should be performed.

\section{REFERENCES}

1. Ferenczy A. Pathophysiology of adenomyosis. Hum Reprod Update 1998; 4:312.

2. English DP, Verma U, Pearson JM. Uterine cyst as a cause of chronic pelvic pain: a case report. J Reprod Med. 2012;57:446-448.
3. Ejeckam GC, Zeinab OA, Salman M, Bobeck HE. Giant adnomyotic cyst of the uterus. Br J Obstet Gynecol 1993;100:596-598.

4. Kamio M, Taguchi S, Oki T, et al. Isolated adenomyotic cyst associated with severe dysmenorrhea. J Obstet Gynaecol Res 2007;33:388-391.

5. Tamura M, Fukaya T, Takaya R, et al. Juvenile adenomyotic cyst of the corpus uteri with dysmenorrhea. Tohoku J Exp Med 1996;178:339-344.

6. Slezak P, Tillinger KG. The incidence and clinical importance of hysterographic evidence of cavities in the uterine wall. Radiology 1976;118:581-586.

7. Koga $\mathrm{K}$, Osuga $\mathrm{Y}$, Hiroi $\mathrm{H}$, et al. A case of giant cystic adenomyosis. Fertil Steril 2006; 85: 748-749.

8. Evsen MS, Sak ME, Soydinç HE, et al. Adenomyomatous polyp causing acute urinary retention in a postmenopausal woman. J Clin Exp Invest 2011;2:312314.

9. Tamai K, Togashi K, Ito $T$, et al. MR imaging findings of adenomyosis: correlation with histopathologic features and diagnostic pitfalls. Radiographics 2005;25:21-40.

10. Giana M, Montella F, Surico D, et al. Large intramyometrial cystic adenomyosis: a hysteroscopic approach with bipolar resectoscope: case report. Eur J Gynaecol Oncol 2005;26:462-463. 